\title{
Reconnaissance of the
}

\section{Jeology and Ground-Water}

\section{Resources in the Aurora Area}

\section{St. Louis County, Minnesota}

By ROBERT W. MACLAY

.ONTRIBUTIONS TO THE HYDROLOGY OF THE UNITED STATES

SEOLOGICAL SURVEY WATER-SUPPLY PAPER 1809-U

Prepared in cooperation with the Department of Iron Range Resources and Rehabilitation

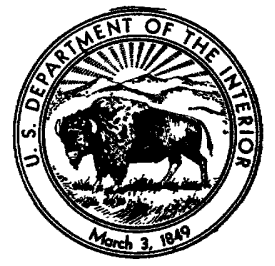




\title{
UNITED STATES DEPARTMENT OF THE INTERIOR
}

STEWART L. UDALL, Secretary

\author{
GEOLOGICAL SURVEY
}

William T. Pecora, Director

For sale by the Superintendent of Documents, U.S. Government Printing Ofice Washington, D.C. 20402 - Price 55 cents (paper cover) 


\title{
CONTRIBUTIONS TO THE HYDROLOGY OF THE UNITED STATES
}

\section{RECONNAISSANCE OF THE GEOLOGY AND GROUND- WATER RESOURGES IN THE AURORA AREA, ST. LOUIS COUNTY, MINNESOTA}

\author{
By Robert W. Maclay
}

\begin{abstract}
The Aurora area is a glaciated upland of drift-mantled slopes, channels, swamps, and glacial-lake plains. It covers about 24 square miles of the eastern part of the Mesabi Iron Range in northeastern Minnesota. A deep narrow channel along the Embarrass River, the principal outlet of a former large glacial lake north of the Embarrass Mountains, lies partly within the area.

The deposits in the report area consist of bedrock and unconsolidated glacial drift. The bedrock belongs to the Animikie Group of late Precambrian age and consists of taconite (an iron-rich silicate rock) in the northern part and slightly metamorphosed argillite in the middle and southern parts. Bedrock is exposed only in the open-pit iron mines. Large quantities of ground water are pumped from porous and permeable ore zones in the St. James Mine. Small quantities of ground water are obtainable from openings along bedding planes and fractures in the argillite. Unconsolidated deposits consisting of till and water-laid glacial and alluvial materials mantle the bedrock to depths ranging from about 20 feet in the north-central part of the Aurora area to more than 300 feet near the Embarrass River. Thick deposits of sand and gravel in the Embarrass channel are capable of yielding large quantites of water. At places along the Partridge River glaciofluvial deposits (glacial sediments deposited in running water) could yield moderate to large quantities of water. Sandy to bouldery till yields small quantities of water to domestic wells.

Well yields in the Aurora area range from less than $5 \mathrm{gpm}$ (gallons per minute) to about $250 \mathrm{gpm}$ from a well tapping an ore body. The specific capacity of wells penetrating ore zones ranges from about $7 \mathrm{gpm}$ per foot of drawdown to $25 \mathrm{gpm}$ per foot of drawdown. Although no attempt has been made to develop a high-yield well in the sand and gravel deposits of the Embarrass channel, more than 5,000 $\mathrm{gpm}$ is pumped from sumps which collect water from these deposits in the Embarrass mine. Most domestic wells yield about $5 \mathrm{gpm}$ and are drilled and finished in sand or gravel in either the bouldery till or glaciofluvial deposits.

Ground water from the unconsolidated deposits is hard and commonly contains large, undesirable amounts of iron and manganese. Water from the bedrock aquifers contains less iron and manganese than does water from the unconsolidated deposits.
\end{abstract}




\section{INTRODUCTION}

\section{PURPOSE}

The Aurora investigation is one of several that have been made by the U.S. Geological Survey in cooperation with the Department of Iron Range Resources and Rehabilitation to evaluate the groundwater resources of the Minnesota iron ranges. The purpose of this investigation was to determine the availability of ground water for municipal supplies near Aurora, Minn.

\section{LOCATION AND DESCRIPTION OF AREA}

The Aurora area is in northeastern Minnesota in east-central St. Louis County (fig. 1). The area covers about 24 square miles in $\mathbf{T}$. 58 N., R. 15 W., and lies in the eastern part of the Mesabi Iron Range.

State Highway 35 and a network of local public roads give ready access to most of the area. Much of the area is swampland. The Duluth, Missabe \& Iron Range Railway Co. serves the area as an ore carrier.

The population of the village of Aurora in 1960 was 2,799 (U.S. Dept. Commerce, 1960). However, because the economy of the village depends on the mining industry, the population fluctuates with the increases and decreases in mining activity.

\section{CLIMATE}

The northeastern part of Minnesota has a continental climate, characterized by large annual variations in temperatures. The mean annual temperature at Virginia, nearest weather station to the Aurora area, is $39.3^{\circ} \mathrm{F}$. (U.S. Weather Bur., 1960).

About two-thirds of the 27 inches mean annual precipitation falls in the late spring and summer, principally during thunderstorms. Snowfall normally totals about 70 inches.

\section{METHOD AND SCOPE OF INVESTIGATION}

During the period 1954-61 about 200 wells were canvassed and glacial-outwash channels were mapped on aerial photographs and topographic maps. Most of the hydrologic characteristics of the subsurface materials were interpreted from test-hole logs and well records. Of the 59 test holes that were drilled into then unconsolidated deposits, 22 were drilled with a power auger; most of the remainder were drilled with a hydraulic rotary rig. 


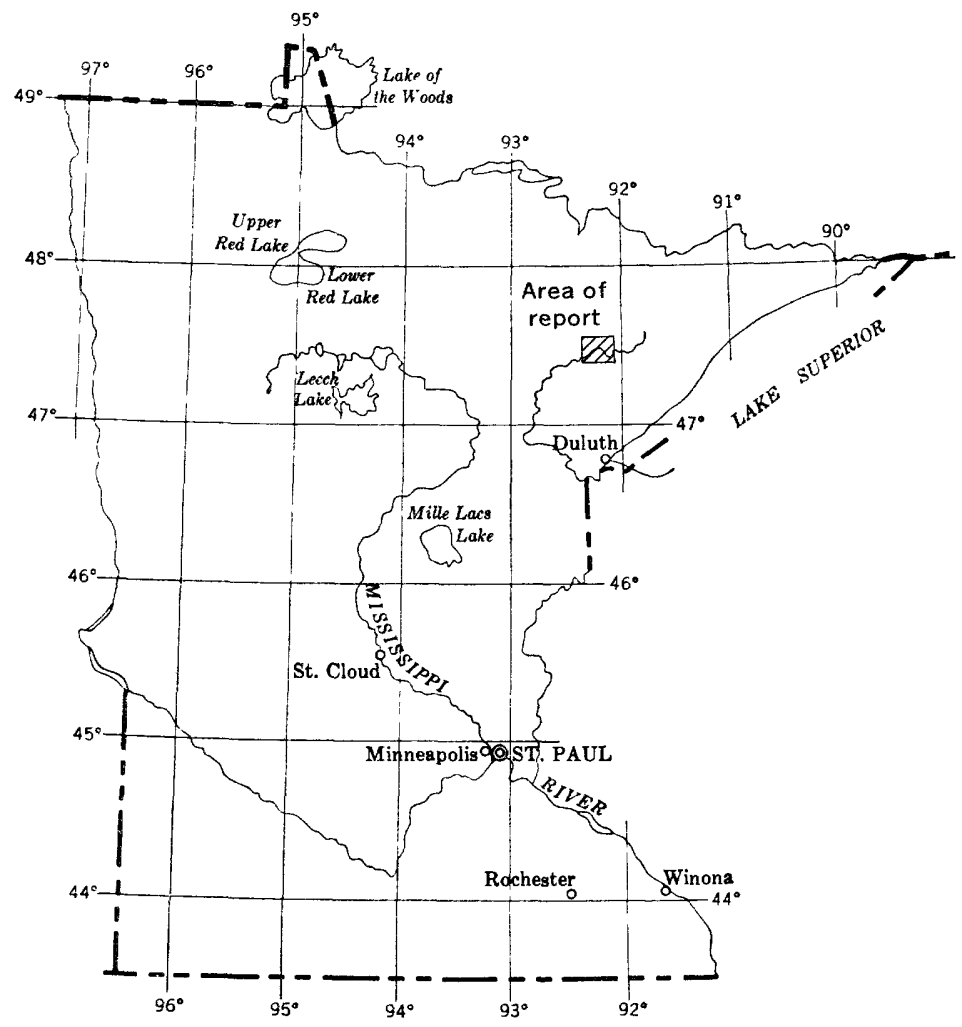

INDEX MAP OF MINNESOTA

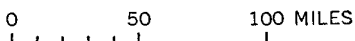

Figure 1.-Location of the Aurora area, Minnesota.

\section{PREVIOUS INVESTIGATIONS}

No comprehensive report on the glacial or ground-water geology of the Mesabi Range has been made. Leverett (1932, p. 120) described the general glacial geology of the region and briefly discussed the origin of the Embarrass Valley. Wright (1956) referred to problems of correlation of glacial formations in northeastern Minnesota; he also published maps of physiographic regions on the basis of landforms. Thiel (1947, p. 211-244) described the occurrence of ground water in the glacial and bedrock formations in St. Louis County and gave the log of an Aurora city well that penetrated the iron-formation. Cotter and Rogers (1961) described the glacial geology and groundwater resources near Virginia, about 15 miles west of Aurora. 
The bedrock formations have been described because of the economic importance of the iron ore. The iron-mining companies have extensively drilled and mapped the iron-formation, but most of their information is unpublished. Leith, Lund, and Leith (1935) and White (1954) made detailed studies of the Biwabik Iron-Formation and the bedrock structure of the Mesabi Iron Range.

\section{WELL-NUMBERING SYSTEM}

The system of numbering wells and test holes is based on the U.S. Bureau of Land Management's system of subdivision of public lands. The Aurora area is in the fourth principal meridian and base-line system. The first segment of a well or test-hole number indicates the township north of the base line; the second, the range west of the principal meridian; and the third, the section in which the test hole is situated. The lowercase letters a, b, c, and d, following the section number, locate the well within the section. The first letter denotes the 160-acre tract, the second the 40-acre tract, and the third the 10-acre tract, as is shown in figure 2. The letters are assigned in a counterclockwise direction, beginning in the northeast quarter. Within one 10 -acre tract consecutive well numbers, beginning with 1 , are added as suffixes.

Figure 2 illustrates the method of numbering a test hole. Thus, the number 58.15.3aab1 identifies the first well or test hole located in the NW $1 / 4 \mathrm{NE}_{1 / 4} \mathrm{NE} 1 / 4$ sec. 3, T. 58 N., R. $15 \mathrm{~W}$.

\section{ACKNOWLEDGMENTS}

The writer thanks well owuers and drillers, village officials, and others in the area who supplied information about wells or rendered other courtesies. Herman Zuponcic, utility commissioner for the village of Aurora, was especially helpful during the investigation.

\section{PHYSIOGRAPHY}

Northeastern Minnesota is in the southern part of the Superior Upland, an extensively glaciated region of many rockbound lakes, low hills, and flat plains (Fenneman, 1938, p. 537). Continental ice sheets overrode this region, gouged out many deep depressions (present lake basins) in the underlying crystalline rocks, and wore down the crests of preexisting hills and ridges. A significant topographic feature of the Superior Upland in northern Minnesota is the Giants Range, including the Embarrass Mountains, which lies about 3-4 miles north of the project area. The Giants Range is a chain of hills extending from the village of Taconite in the west to Birch Lake in the east. It 

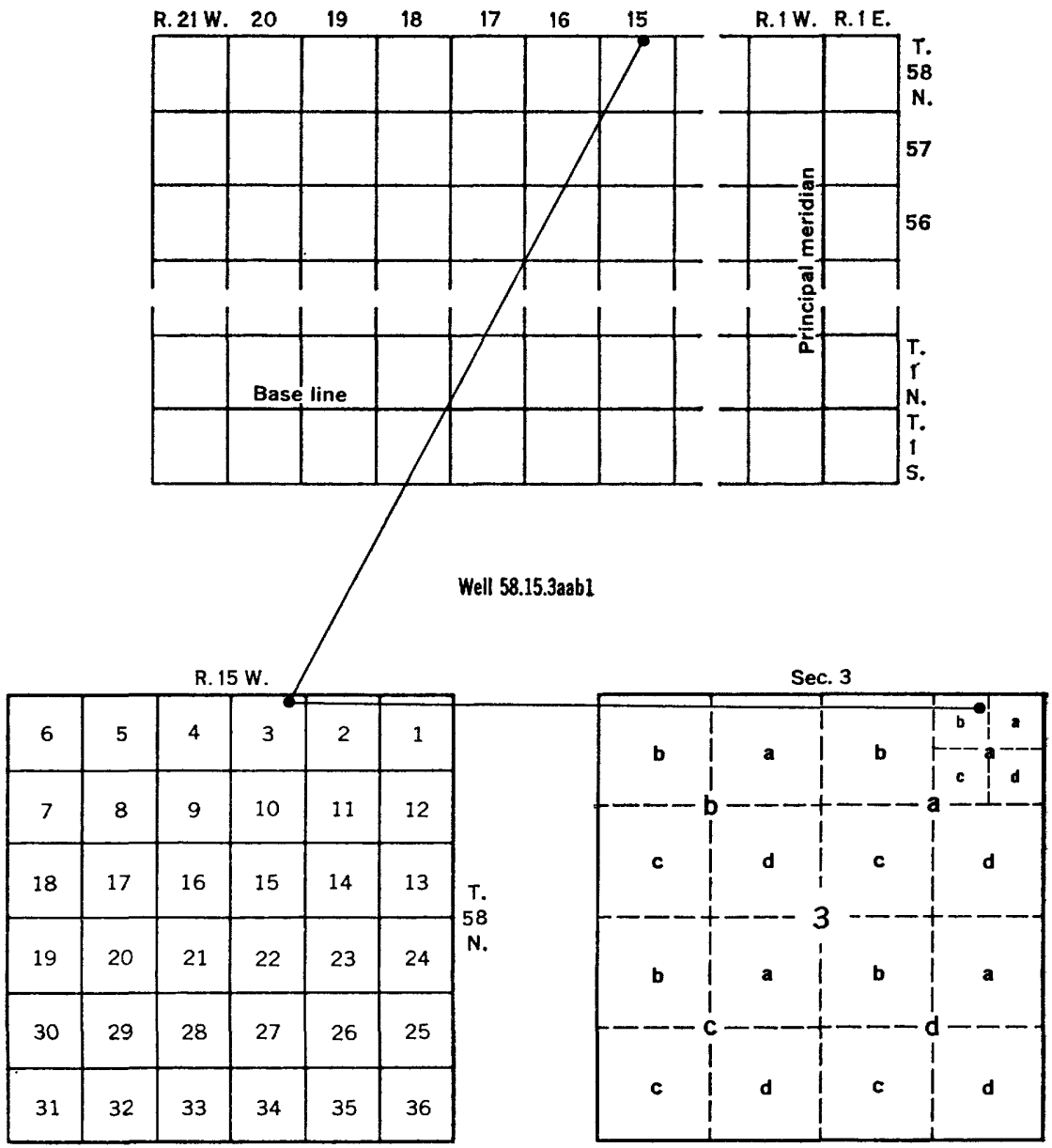

Figure 2.-Method of numbering test holes and wells.

rises as much as 400 feet above the adjacent lowlands in the eastern part of the region but is generally lower toward the west.

Physiographic features within the Aurora area include driftmantled slopes, outwash channels, swamps, and lake plains. Six physical subdivisions of the Aurora area are shown and described on plate 1 (upper left). They are not formal subdivisions, and numbers applied to them are for convenience of reference and discussion. The St. Louis River and its tributary streams the Embarrass and Partridge Rivers drain the Aurora area. Much of the area is poorly drained To permit open-pit mining, the Embarrass River has been diverted from its natural channel near the Embarrass mine and now flows through a diversion ditch in the extreme northwest corner of the area. 


\section{GEOHYDROLOGY}

The rock formations in the Aurora area include Precambrian formations, consisting of hard consolidated rocks, and Quaternary formations, consisting of unconsolidated deposits. A description of the geologic units and their water-bearing characteristics is given in table 1. Most wells in the Aurora area are finished in the unconsolidated deposits. A few deep wells in the consolidated rocks yield large quantities of water.

\section{CONSOLIDATED ROCKS}

The Precambrian rocks of the Animikie Group-the Pokegama Quartzite, the Biwabik Iron-Formation, and the Virginia Argillite (Goldich and others, 1961, p. 188)-unconformably underlie Quaternary deposits and are exposed only in the mines in the northern part of the Aurora area. They consist of well-indurated and metamorphosed conglomerate, graywacke, argillite, quartzite, and ferruginous chert. The ferruginous chert, where altered to iron ore, is commonly porous and permeable.

The Pokegama Quartzite is the basal unit of the Animikie Group. It consists of a basal conglomerate containing fragments from underlying older rocks, a thin-bedded micaceous quartzite and argillite in the middle, and a coarse-grained quartzite at the top (Gruner, 1956, p. 184). It is exposed only in the Embarrass mine. Gruner listed the thickness of the Pokegama as about 50 to 75 feet. No wells in the Aurora area penetrate the Pokegama, and it probably will not yield water to wells.

The Biwabik Iron-Formation ranges in thickness from about 600 to 800 feet and underlies the glacial drift along the north margin of the Aurora area. It consists almost entirely of hard, dense ferruginous chert, called taconite, which is almost impermeable where unaltered and unfractured.

Where composed mostly of chert with iron silicates or magnetite, taconite is generally granular; whereas, if the taconite is high in iron carbonates or iron silicates, it is generally slaty (White, 1954, p. 9). The iron ore is leached and oxidized granular taconite and is generally permeable. Altered slaty taconite, commonly called "paint rock," is a soft rock of low permeability.

The Biwabik Iron-Formation is divided into four stratigraphic units. They are, from oldest to youngest, the lower cherty, lower slaty, upper cherty, and upper slaty members. The lower cherty member in the Aurora area consists of interbedded slaty and cherty taconite in the lower part and cherty taconite in the middle and upper parts. This member is about 200 feet thick and contains permeable 
TABLE 1.-Geologic units and their lithologic and water-bearing characteristics in the Aurora area, Minnesota

\begin{tabular}{|c|c|c|c|c|c|}
\hline System & Major units & Subdivision & $\begin{array}{c}\text { Thickness } \\
\text { (ft) }\end{array}$ & Description & $\begin{array}{l}\text { Water supply and } \\
\text { water-bearing } \\
\text { characteristics }\end{array}$ \\
\hline \multirow{6}{*}{ Quaternary } & \multirow{3}{*}{ Recent } & $\begin{array}{l}\text { Swamp } \\
\text { deposits }\end{array}$ & $0-40 \pm$ & $\begin{array}{l}\text { Clay, silt, and fine } \\
\text { sand; locally con- } \\
\text { tain peat. }\end{array}$ & $\begin{array}{l}\text { Not a source of wa- } \\
\text { ter; generally low } \\
\text { permeability. }\end{array}$ \\
\hline & & $\begin{array}{l}\text { Alluvial } \\
\text { deposits }\end{array}$ & $0-10 \pm$ & $\begin{array}{l}\text { Fine to medium } \\
\text { sand, some silt and } \\
\text { gravel. Unit lies } \\
\text { in flood plains of } \\
\text { the St. Louis River. }\end{array}$ & $\begin{array}{l}\text { Not a source of wa- } \\
\text { ter. }\end{array}$ \\
\hline & & $\begin{array}{l}\text { Lake de- } \\
\text { posits }\end{array}$ & $0-15 \pm$ & $\begin{array}{l}\text { Sand, silt, and clay. } \\
\text { Unit lies along the } \\
\text { southwest margin } \\
\text { of the Aurora area. }\end{array}$ & $\begin{array}{l}\text { At places yields } \\
\text { small amounts of } \\
\text { water to domestic } \\
\text { wells. }\end{array}$ \\
\hline & \multirow{3}{*}{$\begin{array}{l}\text { Pleistocene } \\
\text { (Wisconsin) }\end{array}$} & $\begin{array}{l}\text { Red clay } \\
\text { till (Val- } \\
\text { ders Till) }\end{array}$ & $0-50$ & $\begin{array}{l}\text { Till, red to brown, } \\
\text { clayey; generally } \\
\text { contains small ba- } \\
\text { saltic pebbles; local- } \\
\text { ly bouldery; leach- } \\
\text { ed to a lighter tone } \\
\text { in upper I foot. } \\
\text { Unit caps much of } \\
\text { the uplands of the } \\
\text { Aurora area. }\end{array}$ & $\begin{array}{l}\text { Not a source of wa- } \\
\text { ter. }\end{array}$ \\
\hline & & $\begin{array}{l}\text { Glacioflu- } \\
\text { vial de- } \\
\text { posits }\end{array}$ & $<10-140$ & $\begin{array}{l}\text { Silt, sand, and gravel, } \\
\text { as lenticular beds. } \\
\text { Unit thinly capped } \\
\text { in most places by } \\
\text { red clay till but } \\
\text { locally exposed } \\
\text { along channels. } \\
\text { Terrace deposits are } \\
\text { largely sand but in- } \\
\text { clude some kame } \\
\text { deposits composed } \\
\text { predominantly of } \\
\text { fine to medium } \\
\text { sand. Esker de- } \\
\text { posits composed } \\
\text { largely of poorly } \\
\text { sorted sand, gravel, } \\
\text { and boulders. } \\
\text { Channel deposits of } \\
\text { clay, silt, sand, and } \\
\text { fine to coarse } \\
\text { gravel. }\end{array}$ & $\begin{array}{l}\text { Sand and gravel de- } \\
\text { posits are major } \\
\text { sources of water. } \\
\text { Buried kame de- } \\
\text { posits and channel } \\
\text { deposits are prob- } \\
\text { ably the most pro- } \\
\text { ductive aquifers. } \\
\text { Channel deposits } \\
\text { yield large quanti- } \\
\text { ties of ground wa- } \\
\text { ter to sumps at } \\
\text { the Embarrass } \\
\text { mine. Yields to } \\
\text { wells range from } \\
\text { less than } 5 \text { gpm } \\
\text { from silty sand to } \\
\text { as much as } 1,000 \\
\text { gpm from coarse } \\
\text { gravel. }\end{array}$ \\
\hline & & $\begin{array}{l}\text { Bouldery } \\
\text { till }\end{array}$ & $0-100 \pm$ & $\begin{array}{l}\text { Till, sandy. boul- } \\
\text { dery, gray. Gravel } \\
\text { and boulders are } \\
\text { largely composed of } \\
\text { granite or associated } \\
\text { igneous rocks. } \\
\text { Unit is not exposed } \\
\text { except in mines and } \\
\text { locally in eastern } \\
\text { part of area. }\end{array}$ & $\begin{array}{l}\text { Not a major source } \\
\text { of water; however } \\
\text { locally yields wa- } \\
\text { ter to domestic } \\
\text { wells. Yields to } \\
\text { domestic wells } \\
\text { commonly 5-10 } \\
\text { gpm. }\end{array}$ \\
\hline \multirow{3}{*}{ Precambrian } & \multirow{3}{*}{$\underset{\text { Group }}{\text { Animikie }}$} & $\begin{array}{l}\text { Virginia } \\
\text { Argillite }\end{array}$ & $100 \pm$ & $\begin{array}{l}\text { Argillite, hard, dense, } \\
\text { black, fissile. Unit } \\
\text { is exposed in mines. }\end{array}$ & $\begin{array}{l}\text { As much as } 50 \mathrm{gpm} \\
\text { may be obtained } \\
\text { from fracture } \\
\text { openings. }\end{array}$ \\
\hline & & $\begin{array}{l}\text { Blwablk } \\
\text { Iron-For- } \\
\text { mation }\end{array}$ & $600-800$ & $\begin{array}{l}\text { Chert, hard, dense, } \\
\text { ferruginous. Tex- } \\
\text { ture varies from } \\
\text { dense to slaty. }\end{array}$ & $\begin{array}{l}\text { Leached zones of the } \\
\text { ore deposits are } \\
\text { major sources of } \\
\text { ground water. } \\
\text { Yields as much } \\
\text { as } 250 \text { gpm. }\end{array}$ \\
\hline & & $\begin{array}{l}\text { Pokegama } \\
\text { Quartzite }\end{array}$ & $50-75$ & $\begin{array}{l}\text { Quartzite, thin-bed- } \\
\text { ded, hard, dense, } \\
\text { micaceous, and } \\
\text { argillite. }\end{array}$ & $\begin{array}{l}\text { Not a source of wa- } \\
\text { ter. }\end{array}$ \\
\hline
\end{tabular}


zones in the altered cherty taconites, especially near faults. At Aurora the lower slaty member is about 200 feet thick, and much of the lower part is altered to "paint rock." The upper cherty member consists mainly of 200 feet of cherty taconite but also contains some slaty taconite in its upper part. The altered cherty taconite locally contains ground water under artesian pressure where it is capped by "paint rock." The upper slaty member is made up of about 100 feet of altered slaty taconite in the Aurora area. An intrusive syenite sill in the upper cherty member can be traced for about $31 / 2$ miles from a point near Miller pit to section 36, T. 59 N., R. 15 W. (White, 1954, p. 63.) The sill thins toward the north and in places feathers out in the Biwabik Iron-Formation. Locally it immediately underlies the unconsolidated glacial deposits. A well in the syenite reportedly yields $100 \mathrm{gpm}$ from fractures associated with a fault zone that crosses the St. James pit, but in most areas the syenite would not yield water.

The Virginia Argillite (Goldich and others, 1961, p. 188) is a dark fissile dense rock that may yield as much as $50 \mathrm{gpm}$ to wells from fracture openings. It underlies the glacial drift south of the trace of the contact between the Virginia Argillite and the Biwabik IronFormation shown on plate 1 (upper right). Where it immediately underlies unconsolidated deposits, the Virginia Argillite commonly is altered to a mixture of clay and partially weathered argillite fragments in a zone several feet thick. In the Aurora area the Virginia Argillite probably is 100 feet thick.

The Animikie beds generally strike in an east-northeast direction and dip about $10^{\circ} \mathrm{SE}$. They are strongly jointed into three principal sets-N. $10^{\circ}$ E., N. $45^{\circ}$ W., and N. $80^{\circ}$ W.-that are generally long, straight, and nearly vertical (White, 1954, p. 56). Several nearly vertical faults trend northeastward and northward cross the St. James pit, and each fault has a vertical displacement of about 50 feet.

\section{UNCONSOLIDATED DEPOSITS}

Unconsolidated deposits of Pleistocene and Recent age blanket the Aurora area to a depth ranging from less than 20 feet in the northern part of the area to more than 200 feet in the southern part. They range in texture from permeable gravel to nearly impermeable silt and clay and, thus, vary greatly in water-bearing characteristics.

Gravel, composed of fragments of slate from the bedrock and lesser amounts of granite and basalt, is found locally on the buried bedrock surface. The gravel is probably permeable, as indicated by the coarse texture and lack of clay and silt in the drill samples; however, it is not thick or areally extensive. 
Bouldery till forms the basal unit of glacial deposits. It is largely a gray till of granite, greenstone, and argillite fragments ranging in size from fine sand to boulders. It contains very little clay-sized material. Although the till is compact, it is moderately permeable. Some sections of the till contain lenses of permeable well-sorted sand and gravel. The bouldery till ranges in thickness from less than 1 foot to about 100 feet.

Plate 1 (upper right) shows a conspicuous northeast-trending valley extending from sec. 21 to sec. 15 and a tributary valley extending northwest through sec. 16. These channels are cut into the bouldery till.

Glaciofluvial deposits (glacial sediments deposited in running water) overlie the bouldery till in most places but are exposed only along the channels of the Partridge and St. Louis Rivers. They consist of poorly to well-stratified lenticular beds of silt, sand, and gravel that commonly contain a high proportion of silt and fine sand, especially in the buried valleys. In general, the upper part of the glaciofluvial deposits is moderately permeable, especially in channel or valley areas. The lower part is less permeable but contains some lenses of permeable gravel in sec. 9. The thickness of the glaciofluvial deposits ranges from less than 10 feet in the eastern part of the Aurora area to more than 140 feet in the buried channel in the southwestern part of sec. 15 (pl. 1, lower left). Owing to lithologic similarities between the glaciofluvial deposits and the bouldery till, the boundary between these two units was selected by interpretation of electric logs and drill records.

Red clay till, the drift of Valders age, covers most of the upland area and parts of the lowlands. It is composed of clay and a few pebbles; however, in the western part of the Aurora area it contains some boulders. The till is nearly impermeable, and in the uplands it is a barrier to vertical ground-water movement. The red clay till ranges in thickness from less than 1 foot to about 50 feet and averages about 20 feet in the higher areas.

Postglacial lake deposits of fine-grained sand, silt, and clay lie immediately south of the St. Louis River in the southwestern part of the Aurora area. These deposits from a thin cover (about $15 \mathrm{ft}$ ) on the surface of the red clay till. Their permeability is poor to moderate, and they are locally saturated.

Alluvial deposits of Recent age occur along the St. Louis and Partridge Rivers. They consist of 10 feet or less of stratified fine to coarse sand, silt, and medium gravel. These deposits are moderately permeable. 
Recent swamp deposits consist of clay, silt, fine sand, and peat of low permeability. They may be as much as 40 feet thick in some of the large depressions south of the Duluth, Missabe \& Iron Range Railway Co. in the western part of the Aurora area.

\section{WATER RESOURCES}

\section{PUMPAGE AND USE}

Nearly all water consumed in the Aurora area is ground water. The village of Aurora pumps between 200,000 and 250,000 gpd (gallons per day) (1960), principally from well 58.15.3bcc2, which taps glacial sand and gravel, and from standby well 58.15.3bcd, which taps the Biwabik Iron-Formation. Because of below-averge precipitation during 1960 and 1961, the village wells yielded an insufficient supply of water to meet needs. To supplement their supply, permission was obtained from the Oliver Iron Mining Co. to use a well (58.15.3cca2) that taps the iron-formation. Pumpage from this well and from two others normally used to dewater the St. James pit totals about 400 gpm.

Most water pumped in the area is from the Embarrass mine (pl. 1 , upper left), where a sustained yield of $5,000 \mathrm{gpm}$ is obtained from sumps which collect ground water discharged mostly from sand and gravel in the channel of the Embarrass River. Most farm wells in the Aurora area tap permeable lenses in the glacial deposits. The largest user of water in the vicinity is the steamplant of the Minnesota Power \& Light Co. at Hoyt Lakes, about 1 mile east of the northeast boundary of the Aurora area. In 1960 the nonconsumptive use of surface water at this plant was about 46 billion gallons.

\section{GROUND WATER}

\section{SOURCE, MOVEMENT, AND DISCHARGE}

Recharge to the unconsolidated aquifers occurs chiefly during the middle and late spring, when snowmelt waters infiltrate permeable zones in the thawed ground and evapotranspiration is at a minimum. The average annual recharge to ground-water reservoirs in the glaciofluvial deposits is about 3 inches. Some recharge may occur after the end of the growing season and in late fall before the ground is frozen. During the growing season, recharge is negligible because of evapotranspiration losses (discharge of water to the air by direct evaporation and plant transpiration). Generally water levels are lowest in the late winter, because of the extended period of natural drainage to streams and no recharge. 
Recharge to the bedrock aquifers in the Aurora area is by vertical leakage from the overlying unconsolidated deposits and by lateral underflow from adjoining areas. Recharge to the glacial aquifers occurs mainly in the upland areas, where the sandy and bouldery till is exposed. Little recharge takes place in the areas underlain by the red clay till.

The direction of ground-water movement in the Aurora area is toward the valleys or outwash channels. In the central and eastern parts of the area, altitudes of water levels in a few scattered wells indicate a hydraulic gradient from the high areas capped by till toward the channel of the Partridge River. In the northwestern part of the Aurora area, the gradient is generally toward the Embarrass channel and then downstream within the channel. Near the Embarrass mine, however, the gradient is reversed by pumping at the mine. Most natural discharge from glaciofluvial aquifers in the Aurora area occurs along the Embarrass, St. Louis, and Partridge Rivers or their tributaries. Discharge is principally from small springs or seeps and by evapotranspiration where the water table is near the land surface.

An estimate of minimum natural ground-water discharge can be made on the basis of stream discharge during the winter months, when the flow of streams is maintained by ground water. Stream discharges for the St. Louis and Partridge Rivers and Second Creek at gaging stations within the Aurora area are given for January, February, and March 1959 in the following list. The figures represent cubic feet of water flowing per second from each square mile of drainage area and are based on the assumption that the runoff is distributed uniformly in time and area. (U.S. Geol. Survey, 1959, p. 17-19.)

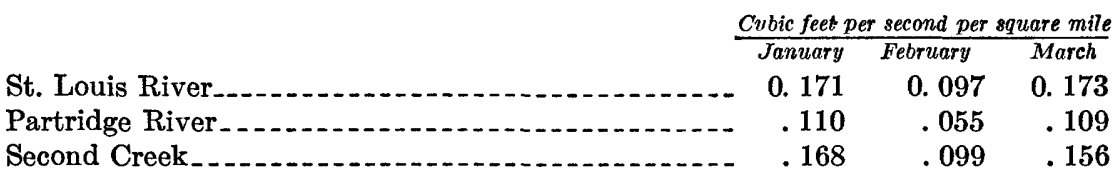

The discharge rate would be substantially greater during the late spring months, when the level of the ground-water reservoir is high. Consequently, more water moves toward the streams in the spring.

\section{WELC YTELDS}

Mine-drainage wells have the highest yields in the Aurora area. Three wells at the St. James pit are used for dewatering. Well $58.15 .3 \mathrm{cba}$ yields $100 \mathrm{gpm}$ from the weather zone in the syenite sill. Wells 58.15.3cca and 58.15.3cdb yield $250 \mathrm{gpm}$ each The last two wells are 455 and 500 feet deep, respectively, and obtain water from openings in the ore body. 
The village of Aurora obtains its municipal water supply from two wells about 0.1 miles north of the St. James pit (pl. 1, upper right). Well 58.15.3bcc2 is 16 inches in diameter and 181 feet deep and yields about $180 \mathrm{gpm}$ from glacial deposits and the Biwabik Iron-Formation. Well 58.15.3bcd1 ( 6 in. in diam. and $90 \mathrm{ft}$. deep) has been pumped at $150 \mathrm{gpm}$ for 24 hours; however, during the winter of 1961 its yield was significantly less. Yields of most farm and domestic wells reportedly are adequate. These wells range from 2 to 6 inches in diameter and have an average yield of about $5 \mathrm{gpm}$.

Specific capacity, the yield of a well per foot of decline (drawdown) in water level, is an indication of the maximum potential yield of wells. For ideal conditions, doubling the yield of a well will also double the drawdown; however, a calculated specific capacity changes with time. For example, the total decline in the period from 1 to 10 minutes should equal the decline in the period from 10 to 100 minutes. For this reason the time since pumping began commonly is stated with the specific capacity of a well.

Specific capacities of a few wells in the Aurora area are as follows:

\begin{tabular}{|c|c|c|c|c|c|c|}
\hline Well & $\underset{(\text { in. })}{D i \text { meter }}$ & $\begin{array}{c}\text { Yield } \\
(g p m)\end{array}$ & $\underset{(h r)}{D \text { uration }}$ & $\begin{array}{l}\text { Drawe- } \\
\text { down } \\
(f t)\end{array}$ & $\begin{array}{c}\text { Specific } \\
\text { capacity } \\
\text { (gpmper } \\
\text { ft })\end{array}$ & Geologic source \\
\hline 58.15.3bcc $\ldots$ & 8 & 75 & $\mathbf{3}$ & 3 & 25 & Sand and gravel. \\
\hline Do_. & 8 & 250 & 10 & 11 & 23 & Do. \\
\hline $58.15 .4 \mathrm{dba}$ & $-\ldots$ & 30 & $1 / 2$ & 7 & 4. 5 & Syenite sill. \\
\hline 58.15.3cea & - & 150 & & 150 & 3 & $\begin{array}{l}\text { Biwabik Iron- } \\
\text { Formation. }\end{array}$ \\
\hline Stephens mine_...- & 8 & 600 & 48 & 45 & 13 & $\begin{array}{l}\text { Biwabik Iron- } \\
\text { Formation } \\
\text { (ore zone). }\end{array}$ \\
\hline
\end{tabular}

The village of Aurora test pumped a 4 -inch test well (58.15.9abb) at the north end of the Aurora channel within the town limits (pl. 1, upper left). This test hole penetrated the upper 6 feet of a sand and gravel deposit that lies between 92 and 106 feet below the land surface. It was pumped at an average rate of $52 \mathrm{gpm}$ for 6 hours with a drawdown of about $31 / 2$ feet and a specific capacity of about 15 . During February 1962 the village of Aurora drilled a production well at the site of test well 58.15.9abb. This well is 10 inches in diameter and completely screened through the sand and gravel. It was pumped at $232 \mathrm{gpm}$ for 10 hours with a drawdown of 52 feet and a specific capacity of about 4.5. The development of the well had not been completed; consequently the specific capacity was less than that of the test well. 


\section{AVAILABILITY OF GROUND WATER}

The areas or units of ground water availability, designated as units 1-6 for convenience of reference, are shown on plate 1 (upper left). The areas are delineated on the basis of physiography and geology inasmuch as these reflect differences in hydrologic conditions.

\section{UNIT 1}

The Embarrass channel, lying below the 1,450-foot contour in the northwestern part of the Aurora area, forms unit 1 . It is a wideterraced area about 80 feet below the adjacent hilly uplands to the east and is the channel that formed the principal outlet of a large glacial lake lying north of the Mesabi Range. The principal features are man-made and include the Embarrass mine, the mine dumps, and the diversion channel.

Glaciofluvial deposits and bouldery till are exposed within the Embarrass channel. Bouldery till lies along the east margin of the channel and grades into glaciofluvial deposits that lie in the central and western parts of the channel. Most of the glaciofluvial deposits consist of coarse stratified sand and gravel, but toward the west margin they contain some silt and clay, which are exposed along the diversion channel. Exposures on the sides of the Embarrass mine show unconsolidated sediments that range in thickness from about 75 feet in the northwest corner to about 300 in the southeast corner. Gray sandy to gravelly outwash is exposed in the western pit area above the bedrock. Gray bouldery till containing oxidized zones overlies a basal yellow fine to medium sand which has a maximum thickness of about 100 feet in the east half of the mine.

Most of unit 1 consists of permeable deposits. The surface is largely sand and gravel and will readily absorb precipitation. For mining operations the Embarrass channel is drained of surface water, and ground-water levels are lowered by pumping. A canal that extends from Wynne Lake immediately north of the Aurora area across the northwest corner of the unit to Embarrass Lake diverts surface flow from the Embarrass channel. The water table in the Embarrass channel is lowered by pumping (about $11 \mathrm{cfs}$ ) at the Embarrass mine. The water level measured in an abandoned mine shaft at 58.15.6cbb was about 92 feet below the land surface, or about 20 feet below the level of Embarrass Lake. If pumping should permanently cease at the mine, the water table in the channel deposits would rise to an altitude probably several feet higher than the level of the lake. Surface water from Embarrass Lake is probably induced into the channel deposits by the pumping at the Embarrass mine. 
Single wells developed in the sand and gravel deposits near the north shore of Embarrass Lake probably would yield as much as $1,000 \mathrm{gpm}$. Estimated ground-water flow through the unit is more than $20 \mathrm{cfs}$.

\section{UNIT 2}

This unit lies along the lower slopes of the iron range in the northcentral part of the Aurora area. It is the highest unit, lying mostly above the 1,500-foot contour, and is formed by a relatively thin cover of glacial drift that overlies a southward-sloping bedrock surface.

Red clay till from less than 1 foot to more than 20 feet thick mantles most of the unit. Bouldery till underlies the red clay till throughout the unit. More than 70 feet of bouldery till is exposed in the Miller pit at Aurora, but this deposit thins toward the north.

Surface-water runoff is relatively high and ground-water recharge is low because the red clay till is nearly impermeable. Only small to moderate quantities (less than $50 \mathrm{gpm}$ ) of ground water can be obtained from the glacial deposits. Probably the largest yields (about $100 \mathrm{gpm}$ ) can be obtained from permeable zones in the Biwabik IronFormation, which underlies the unit at relatively shallow depths.

\section{UNIT 3}

Landforms of this unit are characteristic of those formed in areas of stagnant melting ice. They consist of large steep-walled swamps, ice-contact terraces, small channels, and flat uplands.

Red clay till covers the entire area except for muskeg and Recent swamp deposits in some of the depressions. Bouldery till underlies the red clay till in the northern part of the unit. Glaciofluvial deposits, consisting mostly of stratified sand and gravel in the channel areas and of sand, silt, and clay in the higher areas, underlie the red clay till in the central and southern parts of this unit (pl. 1, lower right).

The principal aquifer in the unit is composed of sand and gravel and is in the upper part of the glaciofluvial deposits at depths that range from about 20 to 50 feet below the land surface. These sand and gravel deposits yield as much as $25 \mathrm{gpm}$ to domestic wells in $58.15 .10 \mathrm{dc}$ and $58.15 .11 \mathrm{~cd}$, and owners of nearly all wells in the unit report that their wells yield sufficient quantities for domestic purposes.

Sand and gravel aquifers at $58.15 .3 \mathrm{bcc}$ may yield as much as 50 gpm to large-diameter wells.

Ice-contact deposits in adjoining areas, similar to those in unit 3, yield $50-100 \mathrm{gpm}$ to wells. The flat-topped ice-contact (kame) deposits in unit 3 will probably yield similar quantities of water. The few holes augered in kame deposits penetrated sorted sand and gravel 
below the red clay till that would probably yield about $100 \mathrm{gpm}$ from single wells.

Precipitation in the uplands is discharged mostly by evapotranspiration from swamp areas, but some recharge probably takes place through the overlying red clay till. In much of the upland areas, the till is a confining bed, and ground water is under artesian conditions. Near the areas of drainage water discharges as seeps and springs.

\section{UNIT 4}

The unit consists of a segment of a moraine that extends from 58.15.2 southeastward beyond the boundary of the Aurora area. The moraine ranges in height from 30 to 60 feet. High flat ice-contact terraces lie along the south margin of the moraine in 58.15.13. A large gap in the moraine occurs along the Partridge River in 58.15.12.

Most of the moraine is composed of bouldery till that contains a high percentage of slate fragments derived from bedrock. Red clay till caps most of the ice-contact deposits southwest of the moraine Glaciofluvial deposits derived from the bouldery till form the terraces. Stratified sand underlies elongate benches in the area immediately north of the confluence of First Creek and Partridge River $\left(\mathrm{NW}^{1} / 4 \mathrm{sec}\right.$. 12$)$.

The most productive aquifers are the outwash deposits. Springs occur in an unnamed outwash channel trending northwestward from the revetment along the west edge of the reservoir in the central area of 58.15.13 and in the channel trending southward from the main dam along the south margin of the reservoir in 58.15.24 (pl. 1, upper left). The springs are probably caused by seepage from the Whitewater and Colby reservoirs. Possibly $100-200$ gpm of ground water is available from single wells in the shallow deposits of stratified sand near Partridge River and Second Creek and from sand and gravel deposits in the low terraces along the St. Louis and Partridge Rivers in 58.15.21, 58.15.22, and 58.15.14 (pl. 1, lower right).

\section{UNIT 5}

The Aurora channel, unit 5, is a narrow channel that extends southward from the northern part of 58.15.9 to the northwestern part of 58.15.21. It is bordered in places by ice-contact deposits (eskers and kame terraces) and contains a small stream. At one time the channel may have drained the headwater area of First Creek.

In the northern part of the Aurora channel, till of Valders age overlies glaciofluvial deposits; however, toward the southern part of the channel, glaciofluvial deposits are exposed. Logs of representative test holes in the Aurora channel are as follows: 
Test hole at $58.15 .9 a b b$

Till, red clay $\underset{(f t .)}{\text { Thickness }} \begin{gathered}\text { Depth } \\ \text { (ft.) }\end{gathered}$

Clay, gray, compact._.

Sand and gravel, water-bearing glaciofluvial deposit..... Till, bouldery, sandy, clayey.

Gravel and sand, water-bearing

Test hole at 58.15.9acc (driller's log)

Clay

$\begin{array}{rr}\begin{array}{c}\text { Thickness } \\ (f t)\end{array} & \begin{array}{c}\text { Depth } \\ (f t)\end{array} \\ 16 & 16 \\ 22 & 38 \\ 12 & 50 \\ 7 & 57 \\ 20 & 77 \\ 4 & 81 \\ 15 & 96 \\ 5 & 101 \\ 3 & 104 \\ 4 & 108\end{array}$

Test hole at 58.15.9cdd (auger hole)

Clay and boulders

Sand and gravel.

Hardpan . . . .

Slit, quicksand, and gravel

Gravel and boulders.

Hardpan . .

Clay

Slate

$\begin{array}{rr}\begin{array}{c}\text { Thickness } \\ (f t)\end{array} & \begin{array}{c}\text { Depth } \\ (f t)\end{array} \\ 2 & 2 \\ 20 & 22 \\ 8 & 30 \\ 20 & 50 \\ 2 & 52\end{array}$

Boulders

Till, sandy clay

Clay, sandy

Sand and gravel

The floor of the northern part of the Aurora channel is swampy because a clay and till mantle support a shallow water table. In the southern part of the channel, where the glaciofluvial deposits are exposed, the channel is better drained.

Three permeable zones were penetrated in a test hole at 58.15.9abb. The first is a shallow perched water body contained in sand lenses within the till and is only a few feet below the surface. This upper zone is recharged mainly by precipitation in the immediate vicinity.

The water level in the second zone is about 27 feet below the land surface and represents the head of the body of water contained in the sand and gravel deposit that lies between 36 and 54 feet below the land surface. This sand and gravel deposit is probably part of the sheet of glaciofluvial deposits that underlies the red clay till throughout the southern part of the Aurora area; however, it may be a separate narrow and sinuous channel deposit of sand and gravel that extends to the Embarrass Mountains along the upper reaches of First Creek. If the sand and gravel deposit in this second zone is part of the larger glaciofluvial deposit, the contained water in the Aurora channel is a part of a larger ground-water reservoir that is recharged by underflow from outside the unit. 
Water from the third zone, a deposit of sand and gravel from 92 to 111 feet below the land surface, rose in the test hole to about 32 feet below the land surface. The lateral extent of the water-bearing sand and gravel is not known; however, it may underlie most of the area. A few deep test holes in other parts of the Aurora area penetrated a similar section, and the glaciofluvial deposits that underlie the bouldery till in the Embarrass mine are similar. Possibly both these deposits are continuous with the sand and gravel in zone 3.

A coefficient of transmissibility of 12,000 gpd per foot for the sand and gravel deposits in the third zone was calculated from data collected during test pumping by the village of Aurora. The coefficient of storage could not be determined from available data; however, for the purpose of evaluation of the aquifer, an assumed value of 0.0001 is considered to be representative for the system described.

Pumping a well will cause a lowering of the water level in the deposits near the well in the form of an inverted cone having the well as its apex. Theoretically a well at the site of the Aurora well (58.15.$9 \mathrm{abb})$ and pumping $60 \mathrm{gpm}$ continually would cause the piezometric surface 100 feet away to lower as follows:

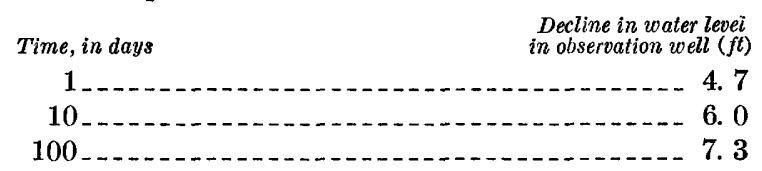

The drawdown of water level in an aquifer is directly proportional to the pumping rate; therefore, if the pumping rate is doubled, the drawdown will double. Probably the drawdown would actually be greater than that indicated because of the local extent of the aquifer and the presence of less permeable materials adjacent to the aquifer.

Wells of moderate yield, 100-300 gpm, can probably be developed in the upper part of the glaciofluvial deposits in the Aurora channel. The sand and gravel deposit lying below the bouldery till (in the upper part of the channel, 58.15.9abb) may yield similar quantities at other places in the channel.

\section{UNIT 6}

This unit is a swampy lake plain in the southwestern part of the Aurora area. The St. Louis River has cut a narrow terraced channel about 20 feet deep into the plain.

Most of the unit is underlain by less than 10 feet of fine to medium sand. Red clay till underlies the sand and is exposed on some mounds. More than 100 feet of fine-grained glaciofluvial deposits underlies the red clay till in 58.15.19 and 58.15.24. The bouldery till is the basal unconsolidated deposit.

Two water zones occur in the sandy lake plain. Locally the upper zone consists of perched water bodies in the lake sands above the red 
clay till. At some places the perched zone will yield domestic supplies to sand-point wells. Recharge is from the local precipitation, which may be insufficient to maintain a permanent water body during dry years. Well owners report that the quality of water from this body is good. The second water zone is within the glaciofluvial deposits underlying the red clay till and is confined by the till except along the St. Louis River. Test drilling indicates that the most permeable glaciofluvial deposits are along the surface channel that drains southward from the stagnant ice upland. Along the channel, wells of moderate yield probably could be developed. Recharge to the glaciofluvial deposits within the unit is mostly by underflow moving from the higher areas to the north. Little recharge occurs through the red clay till. Discharge is through seeps and springs along the St. Louis River.

\section{QUALITY OF GROUND WATER}

The ground-water supply for the village of Aurora is moderately hard (60-120 ppm (parts per million)) and can be used for most purposes without softening. (See analysis below.) Field tests for iron content in water from unconsolidated deposits at 58.15.9abb (north end of unit 5) ranged from $5 \mathrm{ppm}$ for the second zone starting at 36 feet below land surface to $0.5 \mathrm{ppm}$ for the third zone starting at 92 feet. The quality of the water obtained from the bedrock reportedly is similar to that of the unconsolidated deposits; however, it generally has a lower manganese content.

Most private wells reportedly yield hard water. Twenty percent of the owers of private wells reported "rusty" water, indicating that ron or manganese is present. A precipitated band of manganese oxide in a gravel pit on the west side of the Partridge River in the SW1/4 sec. 12 indicates that the ground water associated with at least some of the outwash deposits has a high manganese content.

\section{Analysis of ground-water supply of Aurora}

[Results in parts per million except as indicated. Analysis by the U.S. Geol. Survey]

\begin{tabular}{|c|c|c|}
\hline Location_-_-_-_. 58.15 .3 & $\operatorname{cc} 2$ & Chloride (Cl) _ \\
\hline Date of collection & $25-57$ & Fluoride $(F)$ \\
\hline Depth of well_________ & 180 & Nitrate $\left(\mathrm{NO}_{3}\right)$ \\
\hline Temperature _. & 46 & Dissolved solids (residue at \\
\hline Silica $\left(\mathrm{SiO}_{2}\right)$ & 30 & $\left.180^{\circ} \mathrm{C}\right)$ \\
\hline Iron $(\mathrm{Fe})$ & 3.0 & Hardness as $\mathrm{CaCO}_{3}$ : \\
\hline Manganese $(\mathrm{Mn})$ & 1.1 & Calcium, magnesium_------- \\
\hline Calcium (Ca) & 16 & Noncarbonate \\
\hline Magnesium (Mg) & 10 & Specific conductance \\
\hline Sodium $(\mathrm{Na})$ & 5.4 & $\left(\right.$ micromhos at $\left.25^{\circ} \mathrm{C}\right)$ \\
\hline Potassium (K) & 1.5 & $\mathrm{pH}$ \\
\hline Bicarbonate $\left(\mathrm{HCO}_{3}\right)$ & 96 & Color \\
\hline Sulfate $\left(\mathrm{SO}_{4}\right)_{-}$ & 9.8 & \\
\hline
\end{tabular}




\section{SURFACE WATER}

The average annual runoff in the Aurora area is about 10 inches. The highest runoff normally occurs in the late spring or early summer, and the lowest, during the winter. The maximum discharge of the Partridge River is partly controlled by upstream storage.

The discharges of the three major streams in the Aurora area are summarized as follows:

Mean monthly discharge, in cubic feet per second, for water year 1959

[Records published in U.S. Geol. Survey Water-Supply Paper 1627, pt. 4, 1960]

\begin{tabular}{|c|c|c|c|}
\hline Month & St. Louis River & Partridge River & Second Creek \\
\hline October & 218 & 114 & 15.3 \\
\hline November & 208 & 112 & 17.0 \\
\hline December & 122 & 41. 8 & 7. 02 \\
\hline January & 53. 3 & 17. 1 & 4. 41 \\
\hline February & 30. 3 & 8. 65 & 2. 60 \\
\hline March & 54. 1 & 17.0 & 4. 09 \\
\hline April & 196 & 110 & 24. 1 \\
\hline (- & 475 & 242 & 32.5 \\
\hline - & 457 & 226 & 28. 5 \\
\hline - & 147 & 72.2 & 22. 1 \\
\hline August_. & 99.0 & 45. 8 & 14. 5 \\
\hline September & 264 & 137 & 23. 6 \\
\hline
\end{tabular}

\section{CONCLUSIONS}

Moderate to large quantities of ground water are a vailable from sand and gravel aquifers within the three channels of the major drainages in the Aurora area. The aquifers with the largest potential yield are in the channel of the Embarrass River, where there is more than 70 feet of permeable sand and gravel. Moderate supplies of water are available from deposits in the north end of unit 5 and in the channel of the Partridge River. The village of Aurora has installed a well in the northern part of Unit 5 which draws water from sand and gravel immediately overlying the consolidated rock. This well yields about $230 \mathrm{gpm}$.

\section{REFERENCES}

Cotter, R. D., and Rogers, J. E., 1961, Exploratory drilling for ground water in the Mountain Iron-Virginia area, St. Louis County, Minnesota: U.S. Geol. Survey Water-Supply Paper 1539-A, 13 p.

Fenneman, N.M., 1938, Physiography of Eastern United States: McGraw-Hill Book Co., $605 \mathrm{p}$.

Goldich, S. S., Nier, A. O., Baadsgaard, Halfdan, Hoffman, J. H., and Krueger, H. W., 1961, The Precambrian geology and geochronology of Minnesota: Minnesota Geol. Survey Bull. 41, 188 p.

Gruner, J. W., 1956, The Mesabi Range, in Geol. Soc. America guidebook for field trips, Minneapolis mtg., field trip 1 : p. 182-216. 


\section{U20 CONTRIBUTIONS TO THE HYDROLOGY OF THE UNITED STATES}

Leith, C. K., Lund, R. J., and Leith, Andrew, 1935, Precambrian rocks of the Lake Superior region, a review of newly discovered geologic features, with a revised geologic map : U.S. Geol. Survey Prof. Paper 184.

Leverett, Frank, 1932, Quaternary geology of Minnesota and parts of adjacent States: U.S. Geol. Survey Prof. Paper 161, 149 p.

Thiel, G. A., 1947, The geology and underground waters of northeastern Minnesota: Minnesota Geol. Survey Bull. 31, 243 p.

U.S. Department of Agriculture, 1941, Climate and man: Dept. Agriculture Yearbook, p. 925-934.

U.S. Geological Survey, 1959, St. Lawrence River basin, pt. 4 of Surface water supply of the United States, 1959: U.S. Geol. Survey Water-Supply Paper 1627, p. 17-19.

White, D. A., 1954, The stratigraphy and structure of the Mesabi Range, Minnesota : Minnesota Geol. Survey Bull. 38, 89 p.

Wright, H. E., Jr., 1956, Sequence of glaciation in eastern Minnesota, in Geol. Soc. America guidebook for field trips, Minneapolis mtg., field trip 3: p. 1-23. 